Електронне наукове фахове видання з економічних наук "Modern Economics», №11 (2018), 79-82 https://modecon.mnau.edu.ua | ISSN 2521-6392

JEL Classification: M21

DOI: https://doi.org/10.31521/modecon.V11(2018)-12

Ivanov Vadim, PhD (Technics), Associate Professor of the Management Department, National Transport University, Kiev, Ukraine

Ivanov Denys, PhD (Technics), Tender Center Manager, GEFCO Ukraine

\title{
Business-process introduction according to Compliance requirements in logistics companies
}

\begin{abstract}
Based on the analysis of key business processes in logistics companies, the article discusses the ways of "re-engineering" and improving control for the most common processes: the purchase of goods and supply of services. Their development in accordance with the compliance requirements can improve the competitiveness of the enterprise and achieve compliance with legal and ethical standards. The Compliance system can significantly reduce the probability of financial and reputational risks, as well as corruption acts. Due to the developed business processes, managers and compliancecontrollers, which do not directly interact with the external environment, can timely determine the content of the problem and solve it. The given control system should also be developed for other business process es of the logistics company.

Keywords: Logistic companies; business-processes; internal control; compliance; risks prevention; purchase of goods; supply of services.
\end{abstract}

удк 338.58:65.014

Іванов В. Б., кандидат технічних наук, доцент, доцент кафедри менеджменту, Національний транспортний університет, м. Київ, Україна

Іванов Д., кандидат технічних наук, GEFCO, м. Київ, Україна

\section{Розробка бізнес-процесів в логістичних компаніях відповідно до вимог Комплаєнс}

Анотація. На основі аналізу ключових бізнес-процесів в логістичних компаніях в статті розглядаються шляхи «реінжинірингу» та вдосконалення контролю для найбільш поширених процесів: закупівлі товарів та реалізації послуг. Їх розробка відповідно до вимог комплаєнсу дозволяє підвищити конкурентоздатність підприємства та досягти відповідності правовим та етичним стандартам. Метою дослідження є аналіз основних бізнес-процесів в логістичних компаніях, розробка реінжинірингових та контрольних процесів з метою підвищення якості управління та ефективності виробництва, адаптації кожного процесу таким чином, щоб його результати сприяли досягненню ділової мети та відповідності вимогам та стандартам. На представлені бізнес процеси (закупівля товарів та реалізація послуг) в логістичних компаніях суттєво впливають загрози фінансових та репутаційних ризиків й корупційних дій. Система Комплаєнс дозволяє значно зменшити ймовірність фінансових та репутаційних ризиків, а також корупційних проявів. Завдяки розробленим бізнес-процесам менеджери та комплаєнс-контролери, що безпосередньо не взаємодіють із зовнішнім середовищем, не мають повного набору інформації, можуть вчасно визначити зміст проблеми та розв'язати їі. Водночас, жорстка регламентація діяльності підприємств дозволяє не тільки мінімізувати ризики, але й обмежити їх ініціативу, зупинити розвиток підприємства. Отже, з боку керівництва компанії необхідно визначити певну межу регулювання, яка відображає як фактичний стан підприємства, так і його перспективи розвитку, а також ринкові тенденції та поточні законодавчі зміни. Наведена система контролю повинна бути розроблена також для інших бізнес-процесів логістичної компанії.

Ключові слова: логістичні компанї̈; бізнес-процеси; внутрішній контроль; комплаєнс; запобігання ризикам; закупівля товарів; реалізація послуг.

Problem statement. Logistic, transport, and forwarding enterprises are among the most vulnerable to both economic risks and corrupt acts working in a highly competitive environment. In addition, it is necessary takes into account the specifics of these enterprises activities as elements of business infrastructure, where important factor is to maintain a business reputation, characterized by the absence of negative precedents in fulfilling their obligations, as well as compliance with legal and ethical norms of conduct. It requires from managers of enterprises to develop the mechanism that minimizes the probability of financial losses, as well as loss of trust from the clients, business partners, shareholders, and regulators. They must also provide a permanent corruption counteraction that damages the company's reputation too.

Analysis of recent research and publications. In the research of domestic and foreign scientists, as well as in modern business society, the system of measures aimed at achieving this goal is characterized by the term "compliance", that means functioning 
of the organization in accordance with established principles and definitions, internal policies and procedures based on the requirements of local legislation and widespread international business practice $[1 ; 2 ; 3]$. In accordance with the laws, rules, and standards in the field of compliance, companies usually refer to issues such as the implementation of relevant market behavior standards, conflict of interest management, and fair treatment of clients [4]. The sphere of compliance also includes such specific areas as a counteraction to the legalization of criminal origin proceeds and terrorism financing, documents and procedures development that ensure the company's activities in accordance with the law requirements, information protection, corruption counteraction, ethical norms of employee behavior, etc. [5; 6].

Depending on the sphere of activity, the priority of certain areas of compliance is determined and the company's policy is formed in Fair Investment Policy, Fair Tax Policy, Fair Lending Policy, Fair Purchasing Policy, Fair Sales policy and so on.

Analysis of theoretical studies and implementation experience shows that set of Compliance policies for major part of enterprises includes $[7 ; 8 ; 9 ; 10]$ :

- The Code of Corporate Ethics or Corporate Conduct, which establishes moral and ethical principles, standards of conduct, the priorities of the company and the duties of employees;

- The policy of fair competition, which requires each employee to implement competitive rules and conditions, and is aimed at creating a free market and open competition of goods and services;

- Anti-money laundering policy that protects the legal sector from penetration of shadow revenues;

- The policy of gifts receiving and giving, invitations, which secures the separation of "gift" and "bribe" concepts by establishing the maximum value of gifts and procedures to control over their provision;

- The Whistleblowing Policy, enabling employees, customers, and suppliers to report officially and anonymously about cases of corruption and other violations of standards and norms of conduct;

- A policy that regulates conflicts of interest through the introduction of ethical standards of employee behavior in the event of such conflicts (the interests of the employee's conflict with the interests of the company, the interests of one client with the interests of another, etc.). The policy requires that the interests of the company always be higher than the interests of its individual employees;

- The policy of protecting the company property, which extends both to tangible and intangible values, provides protection of patents, know-how, intellectual property rights;

- Privacy Policy that prevents the disclosure of customer information, regulates the storage and processing of personal data and provides accurate reporting.

Formulating of the article goals. The purpose of the study is to analyze key business processes in logistics companies, develop a re-engineering and control processes of the most common ones in order to improve the quality of management and production efficiency, to tailor each process in such a way that its results contribute to the achievement of the business purpose and meet the requirements of the compliance system.

Main material presenting. The typical approach to reengineering business processes involves the division of routine work of the staff into elementary components, with the further detailed development of each individual business process. Although such an approach requires significant time expenditures, it can reveal bottlenecks, fuzzy formulated tasks, excessively extended functional responsibilities, etc. As a result, management is given the opportunity to delegate part of its responsibility to subordinates to the performer's hierarchy, focusing on strategic planning and development issues. At the same time, an important condition for the perfection of the business process is the possibility for continuous monitoring of the potential problems occurrences and their rapid solution in real time $[11 ; 12]$. Constant monitoring of contractors and people engaged in business contacts involves an assessment of their degree of ability to corruption actions, the level of anticorruption system development in the counterparty company. The subject of external monitoring is also the risks of corruption in interaction with state authorities, in particular, the remuneration needs for participation in procurement tenders for public funds, for expediting procedures, for obtaining of permitting documents, for solving issues in law enforcement agencies and the judicial system. Important parts of the control system are internal control and audits. The internal control system should provide reasonable assurance of operations effectiveness, the reliability of financial accounting and the compliance with law and regulations.

The internal control system implements the risk prevention function by:

- identification, classification, and accounting of risks;

- quantitative assessment of the occurrence probability and possible consequences;- monitoring of risk management effectiveness;- participation in the development of risk mitigation measures and internal documents for risk management;

- identification of interest conflicts in the organization and its employees' activities;

- analysis of the customer comments dynamics and the effectiveness of the implemented measures;

- analysis of the economic outsourcing services feasibility and the contractors' attraction;

- the development of internal documents aimed at commercial bribery and corruption countering;

- development of documents and the organization of measures for the introduction of corporate behavior norms and professional ethics;

- performing other functions that prevent risks and are provided by the internal documents of organizations.

The basis for the creation of all internal control system elements is the control environment, which includes three main components:

- management as an executor of control functions;

- the organization that defines the tasks, competencies, and responsibilities of the staff;

- IT system that provides both production processes and internal control needs.

Management should serve as an example of leaders. Supervision and monitoring are the subjects of management responsibilities. Implementation of an effective internal control system is the management priority function. Duties, competencies, and responsibilities should comply with appropriated organization structure and imply checks and balances in business-processes. An effective IT system should support the business process as well as internal control needs.

Audit evidence shows that key business processes that require constant internal control are the following:- sales of goods and services;

- purchasing of goods;

- cash service, cash, and card payments;

- calculation of compensations for business trips;

- calculation of expenses and preparation of accounts;

- accounting and management of means of production. 
Typical violations of these business processes include:

- non-compliance with standard management procedures executing;

- non-transparent documentation, when important business information and accounting documents are not available;

- exceeding the established authority in the decision-making process;

- violation of the principle of "four eyes", when decisions are taken individually and executed involving several employees;

- shortcomings in the information processing system, which allows false calculations and false information using;

- the absence of databases for clients, which makes impossible to assess their business reputation, creditworthiness, competitiveness, etc.;

-imperfect cost control, leading to the opaque and misplaced use of funds.

Consider the system of internal control on an example of such a universal for all types of enterprises business process, as a procedure of goods and services purchase.

The necessity to regulate and control the goods and services purchasing activity is explained by the existence of the corruption risk by the executors and the probable losses of the company's funds. So, looking at the separate elements we can note that:

- without a clearly defined procedure at each stage of procurement, violations are possible for the sake of individual performers interests;

- without a competitive suppliers selection and corresponding ordering are possible purchases of goods and services with low quality and high prices;

- without a transparent process of order implementation losses of goods and non-fulfillment orders executing are possible;

- without an effective check of accompanying and payment documents false payments, loss of company funds and tax breaches are possible.

Purchase control system (Fig.1) shows the need to comply with the requirements and clear procedures for each employee involved in the process of goods and services acquiring. The main elements of the system are purchase procedures, competitive choice of the supplier and orders shaping, orders implementation and goods and services receipt, invoices checking. Its introduction in logistic companies allows minimizing financial losses' risks of corruption acts or faults.

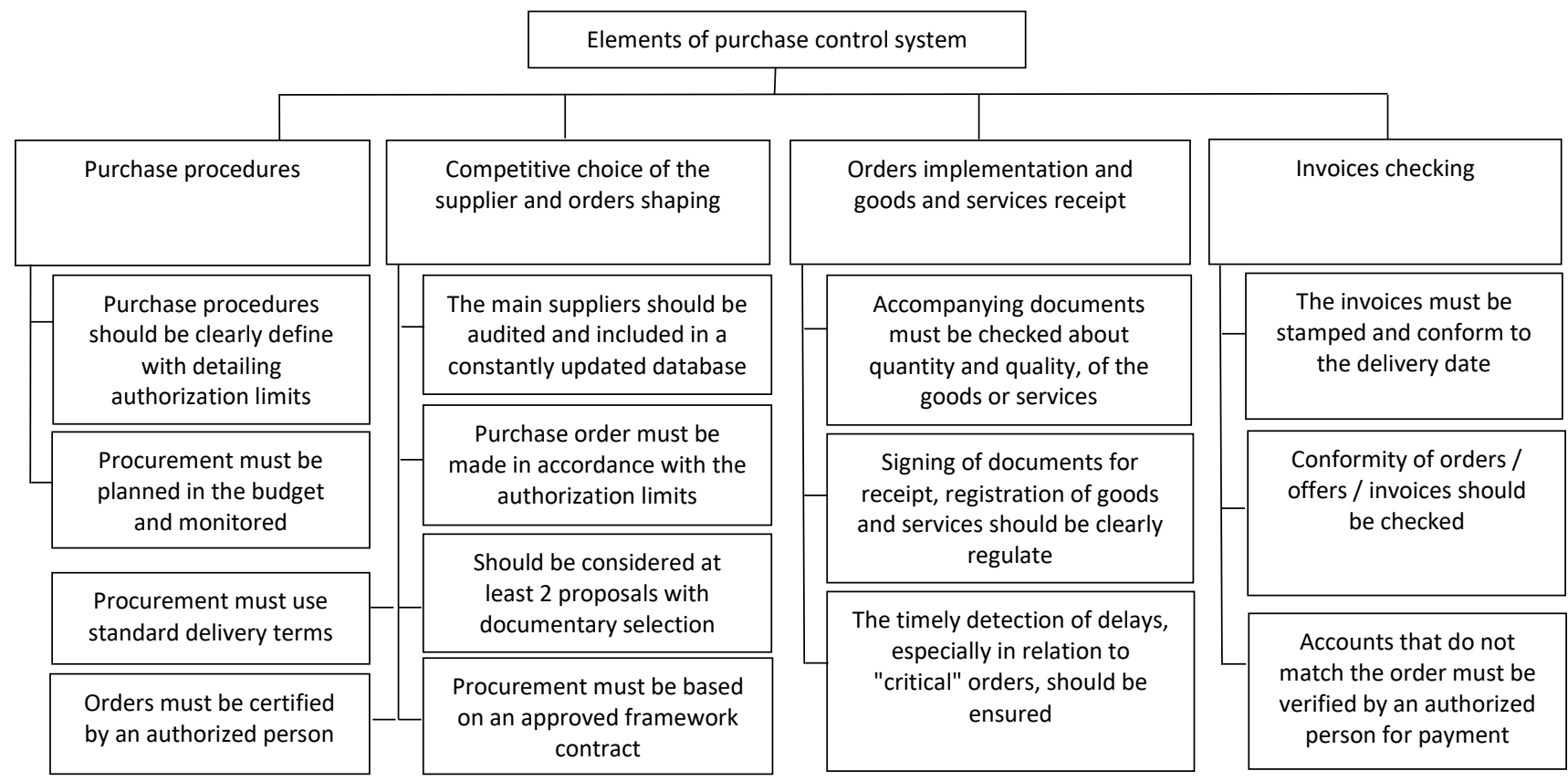

Figure 1. Contents of the purchase control system

Another important procedure, that request a clear regulation and constant internal control is goods and services sales, where there are also risks of income loses as a result of personnel corruption acts or errors. Considering the separate elements of the system of logistic service sales, we note that:

- untimely detection of incorrect expenses calculations connected with services performance may lead to loss-making contracts for the enterprise;

- the lack of effective management of contract performance can lead to violations of execution terms, the scope of work and other contractual conditions;

- both financial and reputational risks of the enterprise are possible when subcontractors without proper selection and control are used for services;

- violation of accounts and performed work acts contents and terms of preparation may lead to loss of funds, the occurrence of tax penalties and negative legal consequences for the enterprise.

To prevent the above risks and losses, the following system of service sales control is proposed (Fig.2).

It covers the following key elements:

- service cost calculation;

- order management;

- third-party services as subcontractors attraction ;

- preparation and execution of accounts and performed work acts.

For each of the above elements, specific requirements are created for the control system, which ensures the avoidance of corrupt actions by the executors and the risk of the company's funds losses. 
Електронне наукове фахове видання з економічних наук “Modern Economics», №11 (2018), 79-82 https://modecon.mnau.edu.ua | ISSN 2521-6392

\begin{tabular}{|c|c|c|c|}
\hline & \multicolumn{2}{|c|}{ Elements of service sales control system } & \\
\hline $\begin{array}{l}\text { Calculation of the services } \\
\text { cost }\end{array}$ & Order management & $\begin{array}{l}\text { Attraction of third-party } \\
\text { services as subcontractors }\end{array}$ & $\begin{array}{l}\text { Preparation and execution of } \\
\text { accounts and performed work }\end{array}$ \\
\hline $\begin{array}{l}\text { Cost calculation } \\
\text { should be executed on } \\
\text { base of unique } \\
\text { confirmed } \\
\text { methodology }\end{array}$ & $\begin{array}{l}\text { The Client's } \\
\text { creditworthiness must } \\
\text { be checked prior to } \\
\text { contract signing }\end{array}$ & $\begin{array}{l}\text { Services of outside } \\
\text { organizations and } \\
\text { private persons must } \\
\text { conform to the content } \\
\text { of the contract } \\
\text { specifications }\end{array}$ & $\begin{array}{l}\text { Contract documentation } \\
\text { should be available for the } \\
\text { of accounts and acts of } \\
\text { performed work } \\
\text { preparation }\end{array}$ \\
\hline $\begin{array}{l}\text { Loss-making orders } \\
\text { must be filtered out } \\
\text { and canceled in a } \\
\text { timely manner }\end{array}$ & $\begin{array}{l}\text { Contracts and Annexes } \\
\text { should be verified and } \\
\text { certified by legal and } \\
\text { financial services }\end{array}$ & $\begin{array}{l}\text { The cost of services } \\
\text { should be carefully } \\
\text { checked in accordance } \\
\text { with the approved cost } \\
\text { estimates }\end{array}$ & $\begin{array}{l}\text { Contents of the accounts } \\
\text { and performed works acts } \\
\text { must comply with the } \\
\text { terms of the Contract }\end{array}$ \\
\hline $\begin{array}{l}\text { Discounts must be } \\
\text { substantiated and } \\
\text { certified by authorized } \\
\text { person }\end{array}$ & $\begin{array}{l}\text { Control of the order } \\
\text { execution must be } \\
\text { realized in accordance } \\
\text { with the approved } \\
\text { production schedule }\end{array}$ & $\begin{array}{l}\text { of subcontractors' } \\
\text { services must comply } \\
\text { of the requirements } \\
\text { Legislation }\end{array}$ & $\begin{array}{l}\text { Automated checking of } \\
\text { contract / offer / } \\
\text { Account / act } \\
\text { correspondence }\end{array}$ \\
\hline
\end{tabular}

Figure 2. Contents of the procurement service sales control system

Conclusions and further research prospects. The presented business processes for goods purchase and services sale in logistics companies suffer the greatest threats of financial and reputational risks and corruption acts. Their development in accordance with the requirements of the Compliance system allows significantly reducing these threats. This will allow managers and compliance-controllers who do not directly interact with the external environment, do not have the entire set of information, to identify timely the content of the problem and find the ways to solve it. Appropriate control systems need to be developed for other above-mentioned business processes.
At the same time, strict regulation of the stuff activities is able not only to minimize risks but also to limit their initiative, to stop the enterprise development. Thus, from the management of the company, it is necessary to define a certain limit of regulation, which reflects both the actual state of the enterprise and its prospects of development, as well as market trends and current legislative changes. Creation and implementation an adequate Compliance policy ensures effective interaction and fair relations between market participants, minimizes legal, financial and reputational risks, promote the development of the enterprise and its personnel.

\section{References:}

1. Pieth, M. (2011). Anti-Korruptions-Compliance : Praxisleitfaden für Unternehmen. Dike, Zürich, 157.

2. Wieland, J. Steinmeyer, R. Grüninger, S. (2015). "Handbuch Compliance-Management. Konzeptionelle Grundlagen, praktische Erfolgsfaktoren, globale Herausforderungen", Erich Schmidt Verlag, 44-47.

3. Behringer, S. (2010). “Compliance kompakt - BestPractice im Compliance-Managemen”, Erich Schmidt Verlag, Berlin, 317.

4. Voloshenko. A. V. (2014). "Komplayens -praktika yak pereventynnyi metod borotby z korupciyeyu”, Aktualni problem ekonomiky, no. 7, pp. 405-413.

5. Cyucyak, A.L. and Cyucyak, I.L. (2011). "Vprovadzhennya systemy komplayens kontrolyu u vitchiznyanu system nezalezhnogo finansovogo kontrolyu ta auditu", Naukovo-informaciynyi visnyk. Ekonomika, no. 3, pp. 200-206.

6. Dubov, D.A. (2016). "Vnedreniye sistemy komplayens kontrolya v kreditnykh organizaciyakh”, Inovacionnaya nauka, no. 2-1 (14), pp. 118-120.

7. Van Kommer, B. and Alink, M. (2017). "Risk-management dlya krupnikh nalogoplatelshikov I problema komplayens", Finansy, no. 1, pp. 24-29.

8. Ambrozhevich, O. (2011). "Komplayens: s nim i bez nyego", Vestnik NAUFOR, no. 9, pp. 54-60.

9. Palcun, I.M. (2013). "Compliance-polityka yak skladova korporatyvnoyi kultury pidpryemstva”, Torgivlya i rynok Ukrayiny, vol. 35, pp. 134-141.

10. Ivanov, V.B. (2018). "Vprovadzhennya systemy Komplayens v pidpryemstvakh transportu ta logistyky", Prychernomorski ekonomichni studiyi, vol. 27/2018, pp. 139-143.

11. Shemayeva, L.G. and Bezgin, K.S. (2011). Upravlinnya yakistyu bizness-procesiv na pidpryemstvi, Vyd-vo KhNEU, Ukraine.

12. Boychuk, N.Y. and Orel, V.V. (2016). "Optynizaciya upravlinnya bizness-procesamy na pidpryemstvakh Ukrayiny", Zbirnyk naukovykh prac Nacionalnogo tekhnichnogo universytetu «KPI», vol.17, pp.173-180.

13. Ishmuhametov, I. and Kuzmina-Merlino, I. (2017). "What Motivates a Learner Manager of a Logistic Company to Achieve Financial Literacy?", Procedia Engineering, vol. 178, pp. 76-84. https://doi.org/10.1016/j.proeng.2017.01.065 (Accessed 01 October 2018).

14. Fernando, Y. and Chukai, Ch. (2018). "Value Co-Creation, Goods and Service Tax (GST) Impacts on Sustainable Logistic Performance", Research in Transportation Business \& Management. https://doi.org/10.1016/j.rtbm.2018.10.001 (Accessed 01 October 2018).

15. Yuan, Y., Feng, Bo, Lai, F. and Collins, B. J. (2018). "The role of trust, commitment, and learning orientation on logistic service effectiveness", Journal of Business Research, vol. 93, pp. 37-50. https://doi.org/10.1016/j.jbusres.2018.08.020 (Accessed 01 October 2018). 